\title{
ANALISIS INFILTRASI BERBAGAI UNIT LAHAN YANG BERBEDA PADA SUB DAS BANYU IRANG DAS MALUKA
}

\author{
INFILTRATION ANALYSIS OF DIFFERENT LAND UNITS IN BANYU IRANG SUB- \\ WATERSHED MALUKA WATERSHED
}

\author{
Friska Aprilia Banjarina, Badaruddin dan Syarifuddin Kadir \\ Program Studi Kehutanan \\ Fakultas Kehutanan, Universitas Lambung Mangkurat. \\ *e-mail: friskaapriliabanjarina@gmail.com
}

\begin{abstract}
The purpose of this study is to analyze the infiltration rate in land units with different types of land cover in the Banyu Irang Sub Watershed in the Maluka Watershed. Analyzing the volume and infiltration capacity of land units with different types of land cover in the Banyu Irang watershed in the Maluka Watershed. The Horton Method was used in this research.. Factors affecting infiltration are soil texture, soil bulk density, total soil porosity, soil organic matter, and soil moisture content. The results show that the highest infiltration rate was found in the secondary forest land cover with a value of $145,5 \mathrm{~mm} / \mathrm{hr}$ on land unit 19 with slope grade between $0-8 \%$ and the lowest infiltration rate was found in alang-alang (reeds) land cover with a value of $3,0 \mathrm{~mm} / \mathrm{hr}$ on land units 32 with slope grade between $15-25 \%$. The highest infiltration capacity and volume occurred in secondary forest land cover with a value of $83,490 \mathrm{~mm} / \mathrm{hr}$ in land units 19. The lowest infiltration capacity and volume occurs in alang-alang (reeds) land cover with a value of $0,787 \mathrm{~mm} / \mathrm{hr}$ on land units 1 and $0,846 \mathrm{~mm} / \mathrm{hr}$ on land units 1 .
\end{abstract}

Keywords: infiltration; land unit; infiltration rate; volume; infiltration capacity.

\begin{abstract}
ABSTRAK
Tujuan dari penelitian ini adalah untuk menganalisis laju infiltrasi pada unit lahan dengan tipe tutupan lahan yang berbeda pada Sub DAS Banyu Irang DAS Maluka. Menganalis besarnya volume dan kapasitas infiltrasi pada unit lahan dengan tipe tutupan lahan yang berbeda pada Sub DAS Banyu Irang DAS Maluka. Metode yang digunakan pada penelitian ini yaitu dengan menggunakan metode horton. Faktor-faktor yang mempengaruhi infiltrasi yaitu tekstur tanah, bulk density tanah, total ruang pori tanah, bahan organik tanah, dan kadar air tanah. Berdasarkan hasil penelitian didapatkan hasil laju, volume dan kapasitas infiltrasi yaitu hasil dari laju infiltrasi yang tertinggi terdapat pada tutupan lahan Hutan Sekunder yaitu 145,5 mm/jam pada unit lahan 19 dengan kelas kelerengan 0-8\% dan laju infiltrasi terendah terdapat pada tutupan lahan Alang-Alang yaitu 3,0 mm/jam pada unit lahan 32 dengan kelas kelerengan 15-25 $\%$. Hasil data yang diperoleh untuk kapasitas dan volume infiltrasi yang tertinggi terjadi pada tutupan lahan Hutan Sekunder yaitu sebesar 83,490 mm/jam pada unit lahan 1 dan 54,190 $\mathrm{mm} / \mathrm{jam}$ pada unit lahan 19. Kapasitas dan volume infiltrasi terendah terjadi pada tutupan lahan Alang-alang yaitu 0,787 mm/jam pada unit lahan 1 dan 0,846 mm/jam unit lahan 1 .
\end{abstract}

Kata Kunci: infiltrasi, unit lahan, laju infiltrasi, volume, kapasitas infiltrasi. 


\section{PENDAHULUAN}

Daerah aliran sungai (DAS) merupakan daratan yang dibatasi oleh topografi bukit atau gunung yang berfungsi untuk menyimpan, menampung dan mengalirkan air hujan menuju sungai atau danau (Asdak, 2010). Bagian hulu dari ekosistem DAS memiliki fungsi penting bagi perlindungan terhadap keseluruhan bagian DAS, perlindungan yang dimaksud yaitu fungsi dari tata air dan tanah. Aliran permukaan air dapat menentukan besarnya air yang masuk ke dalam tanah yang berhubungan dengan tingkat infiltrasi. Semakin tinggi tingkat infiltrasi maka semakin kecil bahaya banjir yang terjadi.

Kemiringan lereng menunjukkan besarnya sudut lereng dalam persen atau derajat. Lereng dengan tingkat kecuraman $100 \%$ memiliki nilai yang sama dengan tingkat kecuraman 45 derajat, lereng yang curam dapat memperbesar jumlah aliran air, lereng yang curam dapat menyebabkan tanah yang terangkut oleh air hujan semakin banyak sehingga erosi semakin meningkat (Arsyad, 2010).

Tata guna lahan yang berubah berpengaruh terhadap ketersediaan air tanah akibat dari perubahan nilai laju infiltrasi yang masuk ke dalam tanah (Sandhyavitri, 2014). Lahan digunakan sebagai sumberdaya yang memiliki hubungan dengan aktivitas manusia untuk memenuhi kebutuhan hidupnya (Worosuprojo, 2007).

Penelitian ini bertujuan untuk menganalisis laju infiltrasi pada unit lahan dengan tipe tutupan lahan yang berbeda pada Sub DAS Banyu Irang DAS Maluka. Menganalis besarnya volume dan kapasitas infiltrasi pada unit lahan dengan tipe tutupan lahan yang berbeda pada Sub DAS Banyu Irang DAS Maluka.

\section{METODE}

Penelitian dilakukan di DAS Maluka selama kurang lebih 3 (tiga) bulan dari bulan Juni 2019 sampai Agustus 2019. Mulai dari persiapan penulisan penelitian, pelaksanaan penelitian, dan pengolahan data.

Alat yang digunakan dalam penelitian ini adalah Global Positioning System (GPS), tally sheet, kamera, palu, jerigen, gayung, infiltrometer, ember, dan laptop. Bahan yang digunakan dalam penelitian ini yaitu air.

Penentuan lokasi dilakukan dengan melakukan overlay dari 3 jenis peta, yaitu peta kelerengan, peta jenis tanah, dan peta penutupan lahan, hal ini dilakukan untuk menentukan unit-unit lahan yang ada di Sub DAS Banyu Irang DAS Maluka.

Jenis data yang digunakan meliputi data primer dan data sekunder. Pengumpulan data primer adalah teknik pengumpulan data dengan melakukan observasi atau pengamatan secara langsung di lapangan. Adapun parameter yang diamati di lapangan adalah: 1.) Penelitian dimulai dengan melakukan survei lapangan untuk menentukan titik pengukuran; 2.) Siapkan alat dan bahan yang diperlukan dalam penelitian; 3.) Lakukan pengukuran laju infiltrasi dengan menggunakan infiltrometer; 4.) Masukkan air ke dalam infiltrometer; 5.) Hidupkan stopwatch untuk menghitung laju infiltrasi dan amati perubahan laju infiltrasi yang terjadi; 6.) Catat perubahan laju infiltrasi selama 5 menit sampai konstan; 7.) Lakukan pengisian air apabila hasilnya belum konstan. Adapun data sekunder diperoleh dari studi literatur, laporan dan informasi dari berbagai pihak instansi pemerintah dan pihak lain yang bersangkutan untuk kelengkapan data yang dibutuhkan dalam penelitian. Data sekunder yang diperlukan dalam penelitian ini meliputi: data tentang gambaran umum lokasi penelitian dan peta-peta (peta administrasi, peta DAS, peta tutupan lahan, peta kelerengan, dan peta jenis tanah). 
Perhitungan data hasil pengukuran laju infiltrasi pada penelitian ini menggunakan rumus Horton. Model Horton adalah salah satu model infiltrasi yang terkenal dalam hidrologi. Horton mengetahui bahwa kapasitas infiltrasi berkurang seiring dengan bertambahnya waktu sehingga mendekati nilai konstan. Model Horton dapat dinyatakan secara sistematis mengikuti persamaan berikut:

$$
\begin{aligned}
& f=f C+(f o-f C) x e^{-k t} \\
& K=\frac{f o-f c}{f c} \\
& v=f c t+\frac{f 0-f c}{K}\left(1-e^{-k t}\right)
\end{aligned}
$$

Keterangan:

$\mathrm{f} \quad=$ Kapasitas infiltrasi $(\mathrm{mm} / \mathrm{jam})$

fo $\quad=$ Laju infiltrasi awal $(\mathrm{mm} / \mathrm{jam})$

fc $\quad=$ Laju infiltrasi tetap/konstan ( $\mathrm{mm} / \mathrm{jam})$

$\mathrm{t} \quad=$ waktu (menit)

$\mathrm{k}=$ Konstanta geofisik

e $\quad=$ Bilangan dasar $(2,718)$

$\mathrm{v} \quad=$ Volume infiltrasi $\left(\mathrm{mm}^{3}\right)$

Kurva kapasitas merupakan hubungan antara kapasitas infiltrasi dengan waktu yang terjadi selama dan beberapa saat setelah terjadinya hujan. Kapasitas infiltrasi secara umum akan tinggi pada awal terjadinya hujan akan tetapi semakin lama kapasitasnya maka akan mencapai penurunan hingga mencapai titik konstan. Besarnya penurunan ini dipengaruhi oleh berbagai faktor yaitu: kelembapan tanah, kompaksi, penumpukan bahan liatan, tekstur tanah, struktur tanah.

\section{Laju Infiltrasi}

\section{HASIL DAN PEMBAHASAN}

\section{Laju infiltrasi pada alang-alang}

Penelitian laju infiltrasi dilakukan pada unit lahan dengan tutupan lahan dan kelerengan yang berbeda. Berdasarkan pengambilan data di lapangan diperoleh data rekapitulasi laju infiltrasi di berbagai tutupan lahan yang sama dengan unit lahan yang berbeda. Rekapitulasi laju infiltrasi pada berbagai tutupan lahan dapat dilihat pada Tabel 1.

\begin{tabular}{|c|c|c|c|c|c|c|c|c|c|c|}
\hline No & $\begin{array}{l}\text { Unit } \\
\text { Lahan }\end{array}$ & $\begin{array}{l}\text { Tutupan } \\
\text { Lahan }\end{array}$ & $\begin{array}{l}\text { Klas } \\
\text { lereng } \\
(\%) \\
\end{array}$ & $\begin{array}{l}\text { Panjang } \\
\text { Lereng } \\
(\mathrm{m})\end{array}$ & Luas & Klasifikasi & $\mathbf{t}$ & fo & fc & fo-fc \\
\hline 1 & UL 1 & Alang-Alang & $0-8$ & 30 & 958,84 & Endoaquepts & 0,42 & 5,0 & 0,5 & 4,5 \\
\hline 2 & UL 5 & Alang-Alang & $8-15$ & 15 & 36,67 & Eutrudepts, Udifluvents & 0,42 & 63,0 & 10 & 53,0 \\
\hline 3 & UL 9 & Alang-Alang & $0-8$ & 150 & 89,99 & Endoaquents & 2,00 & 29,0 & 0 & 29,0 \\
\hline 4 & UL 12 & Alang-Alang & $15-25$ & 35 & 9,88 & Endoaquents & 3,00 & 14,0 & 0 & 14,0 \\
\hline 5 & UL 16 & Alang-Alang & $25-40$ & 540 & 327,89 & Eutrudepts, Eutrudox & 3,00 & 11,0 & 0 & 11,0 \\
\hline 6 & UL 18 & Alang-Alang & $0-8$ & 46 & 134,94 & Kanhapludults & 0,33 & 20,0 & 0 & 20,0 \\
\hline 7 & UL 22 & Alang-Alang & $0-8$ & 190 & 517,51 & Kandiudox, Hapludox & 0,42 & 7,0 & 0 & 7,0 \\
\hline 8 & UL 26 & Alang-Alang & $8-15$ & 80 & 99,69 & Kandiudox & 0,42 & 7,0 & 2 & 5,0 \\
\hline
\end{tabular}

Tabel 1. Rekapitulasi laju infiltrasi pada tutupan lahan alang-alang

Table 1. Recapitulation of the rate of infiltration in the reeds (alang-alang) land cover. 
Analisis infiltrasi berbagai unit...(Banjarina, F.A., et al)

\begin{tabular}{|c|c|c|c|c|c|c|c|c|c|c|}
\hline 9 & UL 29 & Alang-Alang & $8-15$ & 10 & 111,07 & Kanhapludults, Hapludox & 0,50 & 9,0 & 0 & 9,0 \\
\hline 10 & UL 32 & Alang-Alang & $15-25$ & 30 & 142,6 & Kandiudox, Hapludox & 0,50 & 3,0 & 0 & 3,0 \\
\hline
\end{tabular}

Keterangan:

$\mathrm{t}=$ waktu (jam), fo= Infiltrasi Awal (mm/jam), fc= Infiltrasi konstan $(\mathrm{mm} / \mathrm{jam})$, fo-fc=laju infiltrasi $(\mathrm{mm} / \mathrm{jam})$.

Laju infiltrasi awal tertinggi pada tutupan lahan alang-alang pada unit lahan 5 sebesar 53,0 $\mathrm{mm} / \mathrm{jam}$ dengan kelerengan 8-15\% dan laju infiltrasi terendah sebesar 3,0 mm/jam berada pada unit lahan 32 dengan kelas lereng 15-25\%. Infiltrasi di setiap penggunaan lahan dapat berbeda apabila sifat-sifat fisik tanahnya berbeda. Perbedaan penggunaan lahan dapat menunjukkan bahwa setiap vegetasi yang berbeda memiliki sistem perakaran dan sumber bahan organik yang berbeda dengan adanya perbedaan tersebut maka karakteristik sifat fisik tanah juga berbeda pada setiap tutupan lahan (Utaya, 2008). Laju infiltrasi tanah berkaitan dengan perbedaan sifat fisik tanah pada penggunaan (Setyowati, 2007).

Wibowo (2010) menyatakan bahwa waktu mempunyai pengaruh terhadap besar kecilnya infiltrasi, semakin lama waktu infiltrasi maka semakin kecil laju infiltrasinya karena air semakin jenuh sebagian rongga tanah terisi oleh tanah yang menyebabkan air tersebut ruang geraknya semakin kecil maka infiltrasi berhenti.

\section{Laju infiltrasi pada hutan sekunder}

Berdasarkan pengambilan sampel di lapangan didapatkan hasil pengukuran laju infiltrasi pada lahan hutan sekunder dari berbagai lokasi yang dapat dilihat pada Tabel 2.

Tabel 2. Rekapitulasi laju infiltrasi pada tutupan lahan hutan sekunder

Table 2. Recapitulation of the rate of infiltration in the secondary forest land cover.

\begin{tabular}{rllrrlrrrrr}
\hline No. & $\begin{array}{c}\text { Unit } \\
\text { Lahan }\end{array}$ & Tutupan Lahan & $\mathbf{t}$ & Luas & Klasifikasi Tanah & $\begin{array}{c}\text { Klas } \\
\text { lereng } \\
(\%)\end{array}$ & $\begin{array}{c}\text { Panjang } \\
\text { Lereng } \\
(\mathbf{m})\end{array}$ & fo & fc & fo-fc \\
\hline 1 & UL 2 & Hutan Sekunder & 0,50 & 53,21 & Endoaquepts & $0-8$ & 194 & 150,0 & 81 & 69,0 \\
2 & UL 6 & Hutan Sekunder & 0,42 & 99,53 & Eutrudepts, Udifluvents & $8-15$ & 49 & 144,0 & 35 & 109,0 \\
3 & UL 13 & Hutan Sekunder & 0,42 & 1,83 & Endoaquents & $15-25$ & 67 & 50,0 & 5 & 45,0 \\
4 & UL 19 & Hutan Sekunder & 0,67 & 16,24 & Kanhapludults & $0-8$ & 18 & 153,0 & 7,5 & 145,5 \\
5 & UL 23 & Hutan Sekunder & 0,42 & 6,34 & Kandiudox, Hapludox & $0-8$ & 249 & 49,0 & 23 & 26,0 \\
6 & UL 27 & Hutan Sekunder & 0,50 & 28,07 & Kandiudox & $8-15$ & 161 & 19,0 & 7 & 12,0 \\
7 & UL 33 & Hutan Sekunder & 0,50 & 136,86 & Kandiudox, Hapludox & $15-25$ & 230 & 12,0 & 4,0 & 8,0 \\
\hline
\end{tabular}

Keterangan:

$\mathrm{t}=$ waktu (jam), fo= Infiltrasi Awal (mm/jam), fc= Infiltrasi konstan (mm/jam), fo-fc= laju infiltrasi (mm/jam).

Hasil pengukuran laju infiltrasi pada lahan hutan sekunder dengan laju awal tertinggi sebesar $145,5 \mathrm{~mm} / \mathrm{jam}$ pada unit lahan 19 dan laju infiltrasi terendah pada lahan hutan sekunder sebesar $8,0 \mathrm{~mm} / \mathrm{jam}$ pada unit lahan 33 . Laju infiltrasi tertinggi memiliki kelerengan sebesar 0-8 dan laju infiltrasi terendah di kelas lereng 15-25. Thierfelder \& Wall (2009) menyatakan bahwa tanah yang memiliki seresah yang tinggi akan meningkatkan laju infiltrasi dikarenakan memiliki suksesi yang baik di bandingkan dengan lahan yang telah di olah secara terus menerus.

\section{Laju infiltrasi pada perkebunan}

Berdasarkan pengambilan sampel di lapangan diperoleh hasil pengukuran laju infiltrasi pada lahan perkebunan dari berbagai lokasi yang dapat dilihat pada Tabel 3. 
Tabel 3. Rekapitulasi laju infiltrasi pada perkebunan.

Table 3. Recapitulation of the rate of infiltration in plantation area.

\begin{tabular}{|c|c|c|c|c|c|c|c|c|c|}
\hline No & $\begin{array}{l}\text { Unit } \\
\text { Lahan }\end{array}$ & $\begin{array}{l}\text { Tutupan } \\
\text { Lahan }\end{array}$ & $\mathbf{t}$ & Luas & Klasifikasi tanah & $\begin{array}{c}\text { Klas } \\
\text { lereng } \\
(\%)\end{array}$ & fo & fc & fo-fc \\
\hline 1 & UL 3 & Perkebunan & 0,42 & $9.533,90$ & Endoaquepts & $0-8$ & 117,0 & 45 & 72,0 \\
\hline 2 & UL 7 & Perkebunan & 0,42 & 271,10 & Eutrudepts, Udifluvents & 8-15 & 15,0 & 10 & 5,0 \\
\hline 3 & UL 10 & Perkebunan & 0,42 & $4.607,61$ & Endoaquents & $0-8$ & 62,0 & 12 & 50,0 \\
\hline 4 & UL 14 & Perkebunan & 0,50 & 182,45 & Hapludox & $15-25$ & 26,0 & 6 & 20,0 \\
\hline 5 & UL 20 & Perkebunan & 0,58 & $2.795,82$ & Kanhapludults & $0-8$ & 68,0 & 10 & 58,0 \\
\hline 6 & UL 24 & Perkebunan & 0,42 & $3.138,43$ & Kandiudox, Hapludox & $0-8$ & 15,0 & 10 & 5,0 \\
\hline 7 & UL 28 & Perkebunan & 0,33 & $1.262,37$ & Kandiudox & $8-15$ & 23,0 & 7 & 16,0 \\
\hline 8 & UL 30 & Perkebunan & 0,42 & 223,62 & Kanhapludults, Hapludox & $8-15$ & 22,0 & 8 & 14,0 \\
\hline 9 & UL 35 & Perkebunan & 0,50 & 996,16 & Kandiudox, Hapludox & $15-25$ & 34,0 & 9 & 25,0 \\
\hline
\end{tabular}

Keterangan:

$\mathrm{t}=$ waktu (jam), fo= Infiltrasi Awal (mm/jam), fc= Infiltrasi konstan (mm/jam), fo-fc=laju infiltrasi (mm/jam).

Hasil laju infiltrasi pada lahan perkebunan tertinggi sebesar $72,0 \mathrm{~mm} / \mathrm{jam}$ berada pada unit lahan 3. Laju infiltrasi terendah pada lahan perkebunan sebesar $5,0 \mathrm{~mm} / \mathrm{jam}$ berada pada unit lahan 7. Laju infiltrasi tertinggi memiliki kelas kelerengan 0-8 dan laju infiltrasi terendah di kelerengan 0-8 dan 8-15. Sifat fisik tanah berpengaruh terhadap laju infiltrasi kondisi jenis tanah yang sama dapat menyebabkan laju infiltrasi yang berbeda tergantung vegetasi yang tumbuh pada lokasi tersebut dan kondisi permukaan tanah yang disebabkan oleh pemanfaatan hewan dan manusia.

Perakaran dapat meningkatkan aktivitas mikroorganisme yang menyebabkan peningkatan porositas dan kestabilan struktur tanah. Proses penyerapan air atau laju infiltrasi berlangsung cepat karena besarnya total ruang pori tanah yang menunjukkan tanah tersebut memiliki banyak ruang pori tanah. Kandungan bahan organik tanah yang tinggi dapat mempertahankan kualitas sifat fisik tanah sehingga membantu perkembangan akar tanaman dan kelancaran siklus air (Elfiati \& Delvian 2010).

\section{Laju infiltrasi pada Semak Belukar}

Berdasarkan pengambilan sampel di lapangan di dapatkan hasil pengukuran laju infiltrasi pada lahan semak belukar dari berbagai lokasi yang dapat dilihat pada Tabel 4.

Tabel 4. Rekapitulasi laju infiltrasi pada Semak Belukar.

Table 4. Recapitulation of the rate of infiltration in bush and shrubs.

\begin{tabular}{rllrrlrrrr}
\hline No & $\begin{array}{c}\text { Unit } \\
\text { Lahan }\end{array}$ & Tutupan Lahan & $\mathbf{t}$ & Luas & Klasifikasi tanah & $\begin{array}{c}\text { Klas } \\
\text { lereng } \\
\text { (\%) }\end{array}$ & fo & fc & fo-fc \\
\hline 1 & UL 4 & Semak Belukar & 0,42 & $1.102,79$ & Endoaquepts & $0-8$ & 18,00 & 7 & 11,0 \\
2 & UL 8 & Semak Belukar & 0,50 & 1,97 & Eutrudepts, Udifluvents & $8-15$ & 61,00 & 10 & 51,0 \\
3 & UL 11 & Semak Belukar & 0,42 & 62,38 & Endoaquents & $0-8$ & 38,00 & 5 & 33,0 \\
4 & UL 15 & Semak Belukar & 0,50 & 8,46 & Hapludox & $15-25$ & 25,00 & 10 & 15,0 \\
5 & UL 17 & Semak Belukar & 0,67 & 418,82 & Eutrudepts, Eutrudox & $25-40$ & 50,00 & 2 & 48,0 \\
6 & UL 21 & Semak Belukar & 0,50 & 140,34 & Kanhapludults & $0-8$ & 25,00 & 10 & 15,0 \\
7 & UL 25 & Semak Belukar & 0,50 & $1.302,23$ & Kandiudox, Hapludox & $0-8$ & 17,00 & 6 & 11,0 \\
8 & UL 31 & Semak Belukar & 0,50 & 88,92 & Kanhapludults, Hapludox & $8-15$ & 12,00 & 4 & 8,0 \\
9 & UL 34 & Semak Belukar & 0,42 & 92,92 & Kandiudox, Hapludox & $15-25$ & 8,00 & 5 & 3,0 \\
\hline
\end{tabular}

Keterangan:

$\mathrm{t}=$ waktu (jam), fo= Infiltrasi Awal (mm/jam), fc= Infiltrasi konstan $(\mathrm{mm} / \mathrm{jam})$, fo-fc=laju infiltrasi (mm/jam). 
Hasil laju infiltrasi tertinggi pada lahan semak belukar sebesar $51,0 \mathrm{~mm} / \mathrm{jam}$ berada pada unit lahan 8 dan laju infiltrasi rendah pada lahan semak belukar sebesar $3,0 \mathrm{~mm} / \mathrm{jam}$ berada pada unit lahan 34. Laju infiltrasi tertinggi memiliki kelerengan 8-15\% dan laju infiltrasi terendah dengan kelerengan $15-25 \%$. Tutupan lahan sangat berpengaruh terhadap jumlah dan kecepatan limpasan permukaan. Semak belukar berfungsi untuk mencegah limpasan air yang menghancurkan partikel tanah menjadi lebih kecil. Air yang terinfiltrasi ke dalam tanah selain diserap oleh akar tanaman juga digunakan untuk proses transpirasi.

Lahan semak belukar memiliki nilai kerapatan massanya yang rendah dan diikuti dengan porositasnya yang tinggi, karena porositas tanah yang tinggi lebih mudah meloloskan air. Tanah pada lahan semak belukar tidak terkena benturan air hujan secara langsung karena terhalangi rerumputan ataupun dedaunan tumbuh-tumbuhan liar yang ada di permukaan tanah sehingga struktur tanah tidak mudah hancur dan tanah lebih mudah menyerap air. Menurut Wirosoedarmo, (2009) tanah pada lahan semak belukar tidak terkena benturan air hujan secara langsung karena terhalangi rerumputan ataupun dedaunan tumbuh-tumbuhan liar yang ada di permukaan tanah sehingga struktur tanah tidak mudah hancur dan tanah lebih mudah menyerap air.

\section{Volume dan Kapasitas Infiltrasi}

1. Volume dan kapasitas infiltrasi pada lahan alang-alang

Berdasarkan pengambilan sampel di lapangan didapatkan hasil pengukuran kapasitas dan volume infiltrasi pada alang-alang dari berbagai lokasi yang dapat dilihat pada Tabel 5 , sebelum disajikan Tabel 5 maka dilakukan perhitungan untuk mendapatkan nilai $\mathrm{m}$ dan $\mathrm{k}$ seperti pada grafik Gambar 1.

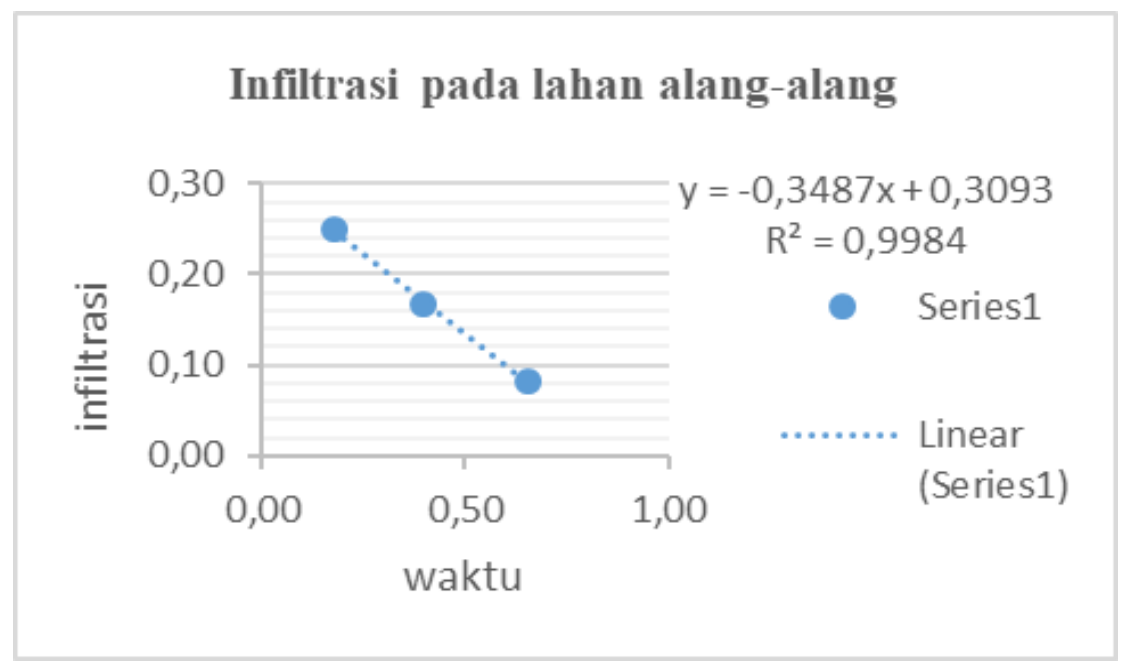

$$
m=-0,35, k=6,61
$$

Gambar 1. Kurva grafik infiltrasi pada lahan alang-alang

Figure 1. Graph of infiltration curve in reeds field.

Berdasarkan hasil yang di dapat pada nilai kurva grafik infiltrasi pada alang-alang didapatkan nilai $m$ sebesar $-0,35$ dan nilai $k 6,61$. Nilai $m$ didapatkan dari nilai y kemudian nilai $m$ digunakan untuk mendapatkan nilai $\mathrm{k}$. 
Tabel 5. Rekapitulasi laju infiltrasi pada Perkebunan

Table 5. Recapitulation of the rate of infiltration in plantation.

\begin{tabular}{ccccccccccc}
\hline No & Unit Lahan & Vegetasi & t & \multicolumn{1}{c}{ fo } & fc & fo-fc & e & k & \multicolumn{1}{c}{$\mathbf{f}$} & v \\
\hline 1 & UL 1 & Alang-Alang & 0,42 & 5,00 & 0,5 & 4,5 & 2,718 & 6,61 & 0,787 & 0,846 \\
2 & UL 5 & Alang-Alang & 0,42 & 63,00 & 10 & 53,0 & 2,718 & 6,61 & 13,378 & 11,676 \\
3 & UL 9 & Alang-Alang & 0,42 & 29,00 & 2 & 27,0 & 2,718 & 1,40 & 17,042 & 9,350 \\
4 & UL 12 & Alang-Alang & 0,58 & 14,00 & 3 & 11,0 & 2,718 & 10,30 & 3,027 & 2,815 \\
5 & UL 16 & Alang-Alang & 0,50 & 11,00 & 3 & 8,0 & 2,718 & 3,00 & 4,788 & 3,573 \\
6 & UL 18 & Alang-Alang & 0,33 & 20,00 & 10 & 10,0 & 2,718 & 2,51 & 14,327 & 5,590 \\
7 & UL 22 & Alang-Alang & 0,42 & 8,00 & 3 & 5,0 & 2,718 & 3,08 & 4,384 & 2,423 \\
8 & UL 26 & Alang-Alang & 0,42 & 11,00 & 3 & 8,0 & 2,718 & $-3,258$ & 34,089 & 8,337 \\
9 & UL 29 & Alang-Alang & 0,50 & 9,00 & 4 & 5,0 & 2,718 & 8,512 & 4,071 & 2,579 \\
10 & UL 32 & Alang-Alang & 0,50 & 3,00 & 1 & 2,0 & 2,718 & 3,010 & 1,444 & 1,017
\end{tabular}

Keterangan:

$\mathrm{t}=$ waktu (jam), fo= infiltrasi awal $(\mathrm{mm} / \mathrm{jam}), \mathrm{fc}=$ infiltrasi konstan $(\mathrm{mm} / \mathrm{jam}), \mathrm{e}=2,718, \mathrm{k}=$ konstanta,

$\mathrm{f}=$ kapasitas infiltrasi $(\mathrm{mm} / \mathrm{jam}), \mathrm{v}=$ volume infiltrasi $\left(\mathrm{mm}^{3}\right)$.

Volume dan kapasitas infiltrasi tertinggi yaitu sebesar 11,676 mm3 berada pada unit lahan 2 dan kapasitas infiltrasi $14,327 \mathrm{~mm} / \mathrm{jam}$ berada pada unit lahan 6 sedangkan volume dan kapasitas infiltrasi terendah sebesar $0,846 \mathrm{~mm} 3$ berada pada unit lahan 1 dan kapasitas infiltrasi $0,787 \mathrm{~mm} / \mathrm{jam}$ pada unit lahan 1 . Buruk nya aerasi dan lambat nya gerakan air yang masuk ke dalam tanah akan mempengaruhi pengisian air tanah pada perakaran tanaman, akibatnya air yang tersedia pada tanaman rendah dengan tingkat curah hujan yang tinggi daya serap air rendah sedangkan pada musim kemarau tanah tersebut mudah sekali mengalami kekeringan sehingga air yang tersedia pada tanaman tersebut tidak ada.

\section{Volume dan kapasitas infiltrasi pada lahan hutan sekunder}

Berdasarkan pengambilan sampel di lapangan di dapatkan hasil pengukuran kapasitas dan volume infiltrasi pada hutan sekunder dari berbagai lokasi yang dapat dilihat pada Tabel 6 , sebelum di sajikan Tabel 6 maka di lakukan perhitungan untuk mendapatkan nilai $\mathrm{m}$ dan $\mathrm{k}$ seperti pada grafik Gambar 2.

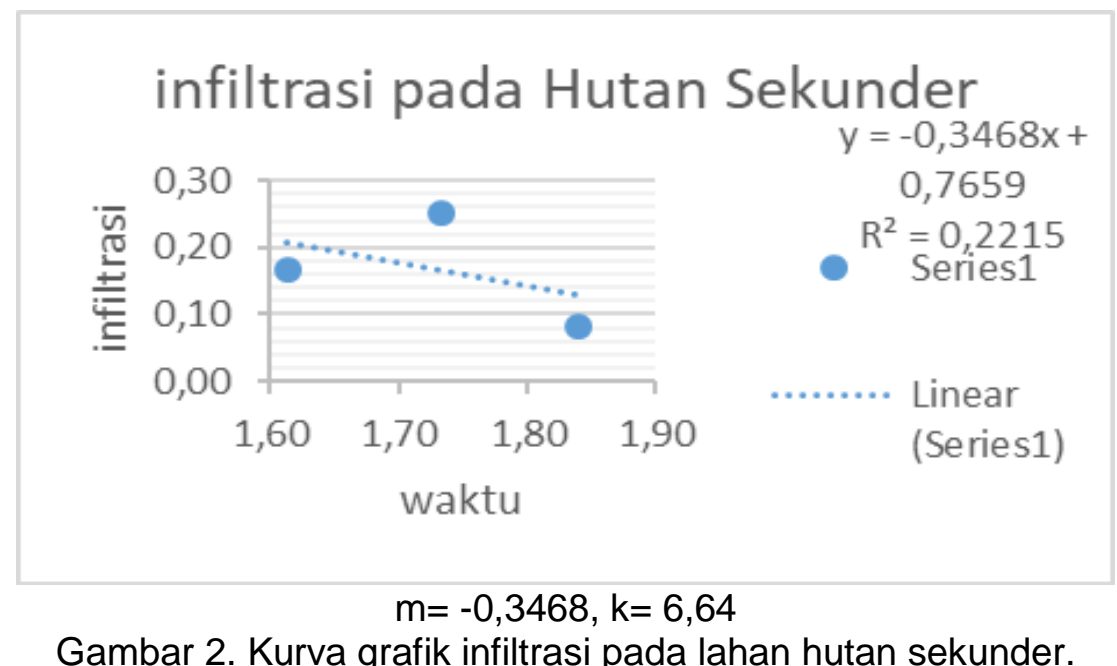

Gambar 2. Kurva grafik infiltrasi pada lahan hutan sekunder. Figure 2. Graph of infiltration curve in secondary forest. 
Berdasarkan hasil yang di dapat pada nilai kurva grafik infiltrasi pada Hutan Sekunder didapatkan nilai $m$ sebesar $-0,3468$ dan nilai $k$ 6,64. Nilai $m$ didapatkan dari nilai y kemudian nilai $\mathrm{m}$ digunakan untuk mendapatkan nilai $\mathrm{k}$.

Tabel 6. Rekapitulasi kapasitas dan volume infiltrasi pada hutan sekunder.

Table 6. Recapitulation of the capacity and volume of infiltration in secondary forest.

\begin{tabular}{ccccccccccc}
\hline No & Unit Lahan & Tutupan Lahan & $\mathbf{t}$ & fo & fc & fo-fc & $\mathbf{e}$ & $\mathbf{k}$ & $\mathbf{f}$ & $\mathbf{v}$ \\
\hline 1 & UL 4 & Hutan Sekunder & 0,50 & 150,00 & 81 & 69,0 & 2,718 & 6,64 & 83,490 & 50,510 \\
2 & UL 8 & Hutan Sekunder & 0,42 & 144,00 & 35 & 109,0 & 2,718 & 6,33 & 42,794 & 30,567 \\
3 & UL 11 & Hutan Sekunder & 0,42 & 50,00 & 5 & 45,0 & 2,718 & 2,78 & 19,104 & 13,178 \\
4 & UL 15 & Hutan Sekunder & 0,67 & 153,00 & 7,5 & 145,5 & 2,718 & 2,33 & 38,212 & 54,190 \\
5 & UL 17 & Hutan Sekunder & 0,42 & 49,00 & 23 & 26,0 & 2,718 & 0,18 & 47,143 & 20,024 \\
6 & UL 21 & Hutan Sekunder & 0,50 & 19,00 & 7 & 12,0 & 2,718 & 10,762 & 7,055 & 4,610 \\
7 & UL 25 & Hutan Sekunder & 0,50 & 12 & 4,00 & 8,0 & 2,718 & 12,945 & 4,012 & 2,617 \\
\hline
\end{tabular}

Keterangan:

$\mathrm{t}=$ waktu (jam), fo= infiltrasi awal $(\mathrm{mm} / \mathrm{jam}), \mathrm{fc}=$ infiltrasi konstan $(\mathrm{mm} / \mathrm{jam}), \mathrm{e}=2,718, \mathrm{k}=$ konstanta,

$\mathrm{f}=$ kapasitas infiltrasi $(\mathrm{mm} / \mathrm{jam}), \mathrm{v}=$ volume infiltrasi $\left(\mathrm{mm}^{3}\right)$.

Volume dan kapasitas infiltrasi tertinggi yaitu sebesar $54,190 \mathrm{~mm}^{3}$ pada unit lahan 15 memiliki dan kapasitas infiltrasi $83,490 \mathrm{~mm} / \mathrm{jam}$ pada unit lahan 4 , sedangkan volume dan kapasitas infiltrasi terendah sebesar 2,617 $\mathrm{mm}^{3}$ pada unit lahan 25 dan 4,012 mm/jam pada unit lahan 25. Lahan yang memiliki vegetasi lebih banyak menyerap air, porositas tanah dapat meningkat akibat adanya bahan organik tanah, dan akar-akar tanaman dan mikroorganisme yang ada di dalam tanah. Bahan organik berperan penting untuk memperbaiki sifat fisika tanah dan untuk meningkatkan kapasitas infiltrasi (Putra et al., 2013). Menurut Refliaty \& Marpaung (2010), bahan organik berkaitan dengan pembentukan agregat tanah yang mengalami proses dekomposisi menghasilkan senyawa organik seperti asam-asam organik dan humus yang dapat merekatkan fraksi penyusun tanah menjadi agregat yang utuh.

Laju infiltrasi pada hutan sekunder lebih besar dibandingkan dengan laju infiltrasi di lahan terbuka hal ini disebabkan karena hutan sekunder lebih banyak mendapatkan sinar matahari yang cukup untuk proses penguapan air pada permukaan tanah yang banyak maka dapat mengurangi kandungan air tanahnya banyaknya kandungan seresah yang dihasilkan oleh hutan sekunder dapat mengurangi pukulan air hujan yang dapat merusak sifat fisik tanah pada lahan tersebut.

\section{Volume dan kapasitas infiltrasi pada lahan perkebunan}

Berdasarkan pengambilan sampel di lapangan didapatkan hasil pengukuran kapasitas dan volume infiltrasi pada perkebunan dari berbagai lokasi yang dapat dilihat pada Tabel 7 , sebelum disajikan Tabel 7 maka dilakukan perhitungan untuk mendapatkan nilai $\mathrm{m}$ dan $\mathrm{k}$ seperti pada grafik Gambar 3. 


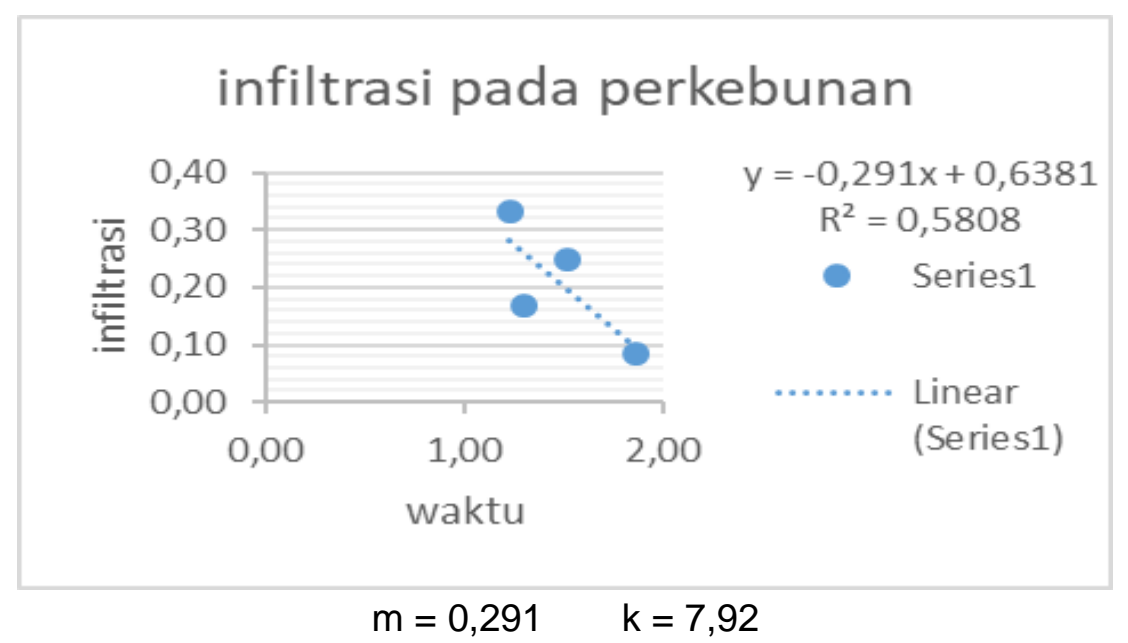

Gambar 3. Kurva grafik infiltrasi pada lahan perkebunan

Figure 3. Graph of infiltration curve in plantation.

Berdasarkan hasil yang didapat pada nilai kurva grafik infiltrasi pada Perkebunan didapatkan nilai $\mathrm{m}$ sebesar 0,291 dan nilai $\mathrm{k} 7,92$. Nilai $\mathrm{m}$ didapatkan dari nilai y kemudian nilai $\mathrm{m}$ digunakan untuk mendapatkan nilai $\mathrm{k}$.

Tabel 7. Rekapitulasi Kapasitas dan Volume Infiltrasi pada Perkebunan Table 7. Recapitulation of the capacity and volume of infiltration in plantation.

\begin{tabular}{lcccccrcrrr}
\hline No & Unit lahan & Vegetasi & $\mathbf{t}$ & \multicolumn{1}{c}{ fo } & fc & fo-fc & $\mathbf{e}$ & $\mathbf{k}$ & $\mathbf{f}$ & $\mathbf{v}$ \\
\hline $\mathbf{1}$ & UL 3 & Perkebunan & 0,42 & 117,00 & 45 & 72,0 & 2,718 & 7,92 & 47,659 & 27,507 \\
2 & UL 7 & Perkebunan & 0,42 & 15,00 & 10 & 5,0 & 2,718 & 13,47 & 10,018 & 4,536 \\
3 & UL 10 & Perkebunan & 0,42 & 62,00 & 12 & 50,0 & 2,718 & 2,61 & 62,982 & 37,374 \\
4 & UL 14 & Perkebunan & 0,50 & 26,00 & 6 & 20,0 & 2,718 & 4,29 & 8,347 & 7,119 \\
5 & UL 20 & Perkebunan & 0,58 & 68,00 & 10 & 58,0 & 2,718 & 4,23 & 14,910 & 18,375 \\
6 & UL 24 & Perkebunan & 0,42 & 15,00 & 10 & 5,0 & 2,718 & 4,33 & 10,824 & 5,131 \\
7 & UL 28 & Perkebunan & 0,33 & 21,00 & 3 & 18,0 & 2,718 & $-3,429$ & 59,440 & 12,211 \\
8 & UL 30 & Perkebunan & 0,42 & 22,00 & 8 & 14,0 & 2,718 & 4,290 & 10,344 & 6,050 \\
9 & UL 35 & Perkebunan & 0,50 & 34,00 & 9 & 25,0 & 2,718 & 9,898 & 9,177 & 7,008
\end{tabular}

Keterangan:

$\mathrm{t}=$ waktu (jam), fo= infiltrasi awal $(\mathrm{mm} / \mathrm{jam}), \mathrm{fc}=$ infiltrasi konstan $(\mathrm{mm} / \mathrm{jam}), \mathrm{e}=2,718, \mathrm{k}=$ konstanta,

$\mathrm{f}=$ kapasitas infiltrasi $(\mathrm{mm} / \mathrm{jam}), \mathrm{v}=$ volume infiltrasi $\left(\mathrm{mm}^{3}\right)$.

Volume dan kapasitas infiltrasi tertinggi yaitu sebesar $37,374 \mathrm{~mm}^{3}$ pada unit lahan 10 memiliki dan kapasitas infiltrasi $62,982 \mathrm{~mm} / \mathrm{jam}$ pada unit lahan 10 sedangkan volume dan kapasitas infiltrasi terendah sebesar $4,536 \mathrm{~mm}^{3}$ pada unit lahan 7 dan kapasitas infiltrasi $9,177 \mathrm{~mm} / \mathrm{jam}$ pada unit lahan 35. Faktor yang memberikan andil lebih besar terhadap peningkatan laju infiltrasi adalah produksi seresah masing-masing tanaman (Arrijani, 2006). Menurut Pramono \& Adi (2017) dalam penelitiannya menjelaskan bahwa besarnya curah hujan yang terinfiltrasi disebabkan oleh ketebalan seresah daun yang ada di bawah permukaan tanah, ketebalan seresah yang terdekomposisi dengan baik semakin banyak air yang ditahan oleh lahan tersebut dan masuk ke dalam lapisan tanah yang lebih dalam sehingga air tidak masuk secara langsung ke dalam tanah, tetapi tertahan oleh ketebalan serasah tersebut sementara waktu. 


\section{Volume dan kapasitas infiltrasi pada lahan semak belukar}

Berdasarkan pengambilan sampel di lapangan didapatkan hasil pengukuran kapasitas dan volume infiltrasi pada semak belukar dari berbagai lokasi yang dapat dilihat pada Tabel 8 , sebelum disajikan Tabel 8 maka dilakukan perhitungan untuk mendapatkan nilai $\mathrm{m}$ dan $\mathrm{k}$ seperti pada grafik Gambar 4.

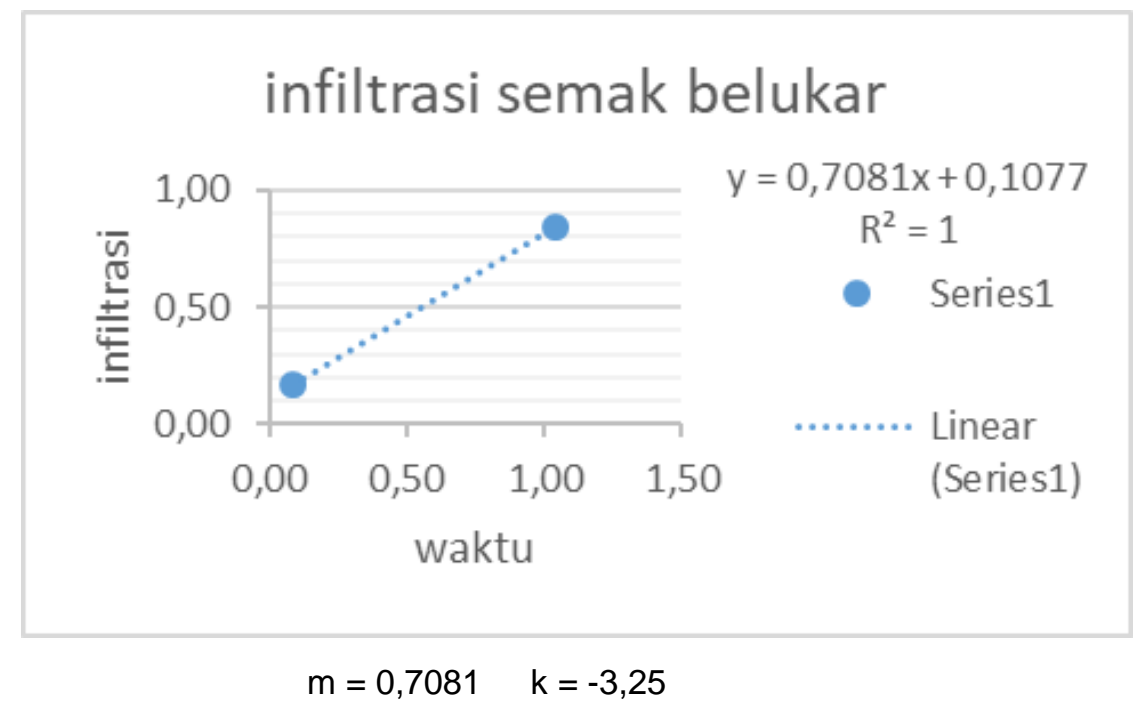

Gambar 4. Kurva grafik infiltrasi pada lahan semak belukar

Figure 4. Graph of infiltration curve in bush and shrubs.

Berdasarkan hasil yang didapat pada nilai kurva grafik infiltrasi pada Semak Belukar didapatkan nilai $m$ sebesar 0,7081 dan nilai $k-3,25$. Nilai $m$ didapatkan dari nilai y kemudian nilai $m$ digunakan untuk mendapatkan nilai $\mathrm{k}$.

Tabel 8. Rekapitulasi Kapasitas dan Volume Infiltrasi pada Semak Belukar Table 8. Recapitulation of the capacity and volume of infiltration in bush and shrubs.

\begin{tabular}{|c|c|c|c|c|c|c|c|c|c|c|}
\hline No & Unit Lahan & Vegetasi & $t$ & fo & fc & fo-fc & e & $\mathbf{k}$ & $f$ & $\mathbf{v}$ \\
\hline 1 & UL 1 & Semak Belukar & 0,42 & 18,00 & 7 & 11,0 & 2,718 & $-3,25$ & 49,674 & 12,650 \\
\hline 2 & UL 2 & Semak Belukar & 0,50 & 61,00 & 10 & 51,0 & 2,718 & 17,93 & 10,007 & 7,844 \\
\hline 3 & UL 3 & Semak Belukar & 0,42 & 38,00 & 5 & 33,0 & 2,718 & 7,68 & 6,348 & 6,207 \\
\hline 4 & UL 4 & Semak Belukar & 0,50 & 25,00 & 10 & 15,0 & 2,718 & 8,33 & 10,233 & 6,773 \\
\hline 5 & UL 5 & Semak Belukar & 0,67 & 50,00 & 2 & 48,0 & 2,718 & 24,49 & 2,000 & 3,294 \\
\hline 6 & UL 6 & Semak Belukar & 0,50 & 25,00 & 10 & 15,0 & 2,718 & 8,33 & 10,233 & 6,773 \\
\hline 7 & UL 7 & Semak Belukar & 0,50 & 17,00 & 6 & 11,0 & 2,718 & 5,310 & 6,773 & 4,926 \\
\hline 8 & UL 9 & Semak Belukar & 0,50 & 12,00 & 4 & 8,0 & 2,718 & 12,945 & 4,012 & 2,617 \\
\hline 9 & UL 10 & Semak Belukar & 0,42 & 8,00 & 5 & 3,0 & 2,718 & $-1,089$ & 9,722 & 3,665 \\
\hline
\end{tabular}

Keterangan:

$\mathrm{t}=$ waktu (jam), $\mathrm{fo}=$ infiltrasi awal $(\mathrm{mm} / \mathrm{jam}), \mathrm{fc}=$ infiltrasi konstan $(\mathrm{mm} / \mathrm{jam}), \mathrm{e}=2,718, \mathrm{k}=$ konstanta, $\mathrm{f}=$ kapasitas infiltrasi $(\mathrm{mm} / \mathrm{jam}), \mathrm{v}=$ volume infiltrasi $\left(\mathrm{mm}^{3}\right)$.

Volume dan kapasitas infiltrasi tertinggi yaitu sebesar $12,650 \mathrm{~mm}^{3}$ pada unit lahan 1 dan kapasitas infiltrasi 49,674 mm/jam pada unit lahan 1 sedangkan volume dan kapasitas infiltrasi 
terendah sebesar 2,617 $\mathrm{mm}^{3}$ pada unit lahan 9 dan kapasitas infiltrasi $4,012 \mathrm{~mm} / \mathrm{jam}$ pada unit lahan 9. Tekstur tanah berpengaruh penting dalam meningkatkan infiltrasi tekstur tanah yang berpasir lebih baik dalam meloloskan air dibandingkan dengan tanah lempung, tanah lempung sangat sulit dalam meloloskan air. Lahan Semak Belukar memiliki tekstur tanah seperti pasir tanah-tanah yang memiliki ukuran struktur yang lebih kecil seperti pasir ini memiliki laju infiltrasi yang lebih tinggi daripada tanah-tanah yang ukuran agregat tanahnya besar.

\section{KESIMPULAN DAN SARAN}

\section{Kesimpulan}

Hasil dari laju infiltrasi yang tertinggi terdapat pada tutupan lahan Hutan Sekunder yaitu 145,5 $\mathrm{mm} / \mathrm{jam}$ pada unit lahan 19 dengan kelas kelerengan 0-8\% dan laju infiltrasi terendah terdapat pada tutupan lahan Alang-Alang yaitu $3,0 \mathrm{~mm} / \mathrm{jam}$ pada unit lahan 32 dengan kelas kelerengan $15-25 \%$.

Hasil data yang diperoleh untuk kapasitas dan volume infiltrasi yang tertinggi terjadi pada tutPupan lahan Hutan Sekunder yaitu sebesar 83,490 mm/jam pada unit lahan 2 dan 54,190 $\mathrm{mm} / \mathrm{jam}$ pada unit lahan 19. Kapasitas dan volume infiltrasi terendah terjadi pada tutupan lahan Alang-alang yaitu 0,787 mm/jam pada unit lahan 1 dan 0,846 mm/jam unit lahan 1 .

\section{Saran}

Berdasarkan hasil penelitian yang telah dilakukan pada tutupan lahan alang-alang memiliki nilai infiltrasi rendah di bandingkan dengan tutupan lahan yang lain sehingga perlu upaya revolusi hijau untuk meningkatkan infiltrasi dan untuk mengurangi aliran permukaan (run off).

\section{DAFTAR PUSTAKA}

Arrijani. (2006). Korelasi Model Arsitektur Pohon dengan Laju aliran Batang, Curahan Tajuk, Infiltrasi, Aliran Permukaan dan Erosi. Disertasi Sekolah Pascasarjana Institut Pertanian Bogor. IPB, Bogor.

Arsyad, S. (2010). Konservasi Tanah dan Air. Edisi kedua. Bogor: IPB Press. 472p. Jakarta.

Asdak, C. (2010). Hidrologi dan Pengelolaan Daerah Aliran Sungai. Gadjah Mada University Press. Yogyakarta.

Elfiati, D., \& Delvian. (2010). Laju Infiltrasi Pada Berbagai Tipe Kelerengan Di Bawah Tegakan Ekaliptus. Jurnal Hidrolitan. 1(2): 29-34.

Horton, P.B., \& Hunt, C.L. (1993). Sosiologi, Jilid 1 Edisi Keenam. (Alih Bahasa: Aminuddin Ram, Tita Sobari). Penerbit Erlangga. Jakarta.

Pramono, I.B. \& Adi, R.H. (2017). Pendugaan Infiltrasi Menggunakan Data Neraca Air di Sub Daerah Aliran Sungai Watujali, Gombong. Jurnal Penelitian Pengolahan Daerah Aliran Sungai 1(1): 35-48.

Putra, A.E., Sumono, Ichwan, N., \& Susanto, E. (2013). Kajian Laju Infiltrasi Tanah pada Berbagai Penggunaan Lahan di Desa Tongkoh Kecamatan Dolat Rayat Kabupaten Karo. J. Rekayasa Pangan dan Pert. 1 (2): 41-43. 
Refliaty \& E. J. Marpaung, (2010). Kemantapan Agregat Ultisol pada Beberapa Penggunaan Lahan dan Kemiringan lereng. J. Hidrolitan. 1 (2): 40.

Sandhyavitri, A. (2014). Kajian Upaya Pelestarian Sumber Daya Air Tanah Kemungkinan Akibat Pembangunan Kebun Kelapa Sawit di Provinsi Riau.

Setyowati, D.L. (2007). Sifat Fisik Tanah dan Kemampuan Tanah Meresapkan Air pada Lahan Hutan, Sawah dan Pemukiman. Jurnal Geografi.

Thierfelder, C., \& Wall, P.C. (2009). Effect of Conservation Agriculture Techniques on Infiltration and Soil Water Content in Zambia and Zimbawe. Soil Tillage Research. 105 (2): 217-227.

Utaya, S. (2008). Pengaruh Perubahan Penggunaan Lahan Terhadap Sifat Biofisik Tanah dan Kapasitas Infiltrasi di Kota Malang. Forum Geografi, 22 (2): 99-112.

Wibowo, H. (2010). Laju Infiltrasi Pada Lahan Gambut Yang Dipengaruhi Air Tanah (Studi Kasus Sei Raya dalam Kecamatan Sei Raya Kabupaten Kubu Raya). Jurnal Belian. 9(1): 90- 103.

Wirosoedarmo. (2009). Dasar Budidaya Tanaman dan Pola Tanam.

Worosuprojo, S. (2007). Pengelolaan Sumberdaya Lahan Berbasis Spasial Dalam Pembangunan Berkelanjutan Di Indonesia. Makalah Pidato Pengukuhan Guru Besar UGM Yojakarta. 